STATE OF ALASKA

DEPARTMENT OF NATURAL RESOURCES

DIVISION OF GEOLOGICAL AND GEOPHYSICAL SURVEYS

February 1973

This report is preliminary and has not been edited or reviewed for conformity with Alaska Geological \& Geophysical Surveys standards.
Alaska Open File Report 12

AEROMAGNETIC MAP, NORTHEAST CORONER

OF GULKANA QUADRANGLE ALASKA 


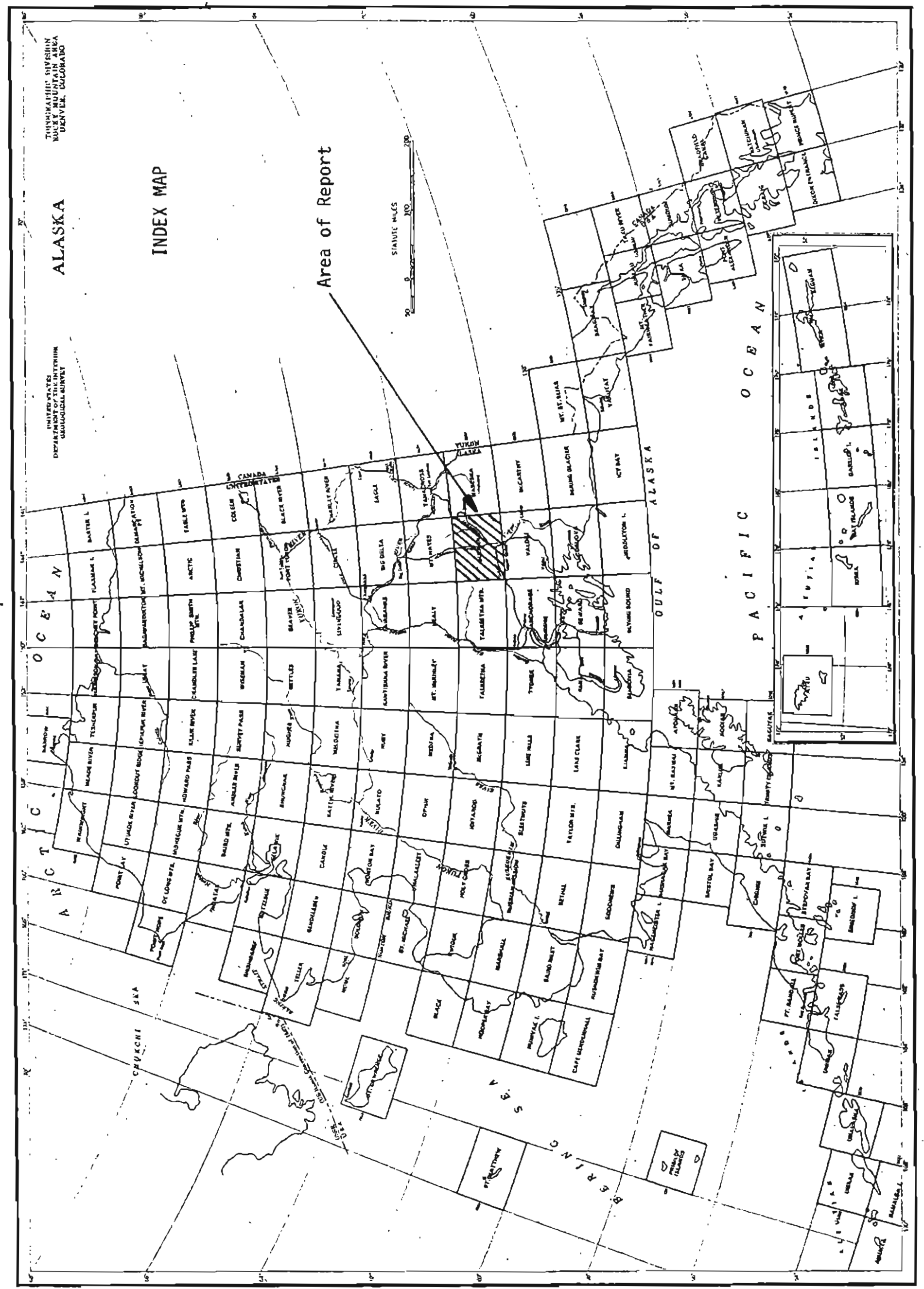




\section{AEROMAGIIETIC PROGRAM}

OF THE

DIVISION OF GEOLOGICAL E GEOPHYSICAL SURVEYS

The Alaska Geological and Geophysical Surveys Aeromagnetic Program is a $100 \%$ state funded exploration project that was started In 1971. Under the direction of the Survey, an aeromagnetic contractor flies the aeromagnetic profiles, compiles the data and prints the maps.

Two hundred (200) maps at $1: 63,360$ scale are printed for sale by the Survey and when this supply is gone an original mylar of each map will be open filed. A composite 1:250,000 map of each USGS quadrangle is also made and open filed as soon as completed. 
1971 - 1973 DATA

The survey flight lines are spaced $3 / 4 \mathrm{mile}$ apart and 1000 feet above ground level where possible. Tie lines were flown at 15 mile intervals normal to the flight lines. The fluxgate magnetometer signal was recorded in flight on a paper strip chart recorder. The diurnal variation was recorded by a ground station. Aircraft altitude was determined by radio altimeter and recorded in flight on a paper strip chart recorder. Aerial photography on $35 \mathrm{~mm}$ black and white film at 3-second intervals was used to plot the aircraft flight path. The regional field was removed from the magnetic data and corrections were made for diurnal variation.

1974 DATA

Survey 1 ines were flown 1 mile apart with 15 mile tie lines. Data recorded digitally. Maps digitally contoured. Details of digital recording and processing available on request.

The original field data are kept in the Division of Geological and Geophysical Surveys offices and may be copied at the expense of the interested person.

For information concerning the aeromagnetlc program, contact the state Geological and Geophysical Surveys, 3001 Porcupine Drive, Anchorage, Alaska 99501, telephone (907) 279-1433. 


$$
(1: 250,000)
$$

\section{OPEN FILE}

1

2

3

4

5

6

7

8

9

10

11

12

13

14

15

16

17

18

19

20

22 .
DATE FLOWN

1971

1971

1971

1971

1971

1971

1971

1971

1971

1971

1971

1971

1971

1971

1971

1971

1971

1972

1972

1972

1972
QUADRANGLE

Selawik

Teller

Bendeleben

Candle

Nome

Solomon

Norton Bay

Fairbanks (south)

Healy

Mt. Hayes

Tanacros 5

Gu.l kana

Habesna

Bethel

Goodrews

Hagemeister I sland Nashagak Bay

Eagle

Talkeetna

Talkeetna Mts.

Anchorage 